\title{
Replacement of liming and NPK fertilization with turkey litter in degraded areas grown with Urochloa decumbens
}

\section{A cama de peru substitui a calagem e a adubação com NPK no cultivo de Urochloa decumbens em área degradada}

\author{
Andrisley Joaquim da Silva ${ }^{1 *}$; Fernando França da Cunha ${ }^{2 *}$; \\ Cassiano Garcia Roque ${ }^{3}$; Monice Donatila Tavares da Silva ${ }^{1}$; \\ Diego Oliveira Ribeiro ${ }^{4}$; Manuel Rodriguez Carballal ${ }^{1}$
}

\begin{abstract}
Soil fertility and acidity correction in recovering areas require high doses of correctives and fertilizers. Therefore, the use of low-cost products may be an alternative in infertile areas. The objective of this study was to evaluate the effect of soil fertilization and correction methods on the yield of degraded areas cultivated with Urochloa decumbens and soil chemical attributes. The study was conducted in Orthic Quartzarenic Neosol in Mineiros, Goiás, Brazil, from October 2011 to September 2013. The experiment included soil samples treated with $2 \mathrm{Mg} \mathrm{ha}^{-1}$ of dolomitic limestone, a standard fertilizer (45, 54 , and $75 \mathrm{~kg} \mathrm{ha}^{-1}$ of $\mathrm{N}, \mathrm{P}$, and $\mathrm{K}$, respectively), or $3 \mathrm{Mg} \mathrm{ha}^{-1}$ of turkey litter, and a control sample without correction/fertilization. Each treatment included four replicates in a completely randomized block design. The experimental plots consisted of areas of $4.0 \mathrm{~m}^{2}(2.0 \times 2.0 \mathrm{~m})$. The dry matter yield of forage grass and the following soil chemical attributes were evaluated: organic matter, hydrogen potential ( $\mathrm{pH}$ in $\mathrm{CaCl}_{2}$ ), phosphorus (resin), potassium, calcium, magnesium, cation exchange capacity (CEC), and base saturation. The data were subjected to analysis of variance, and the means were compared using Tukey's test at a level of significance of 0.05 . Fertilization did not affect the $\mathrm{pH}$, potassium, and CEC of the soil. Fertilization with turkey litter increased the levels of organic matter, phosphorus, calcium, magnesium, and base saturation compared with soils subjected to standard fertilization or liming. Furthermore, soils fertilized with turkey litter presented higher dry matter yield of Urochloa decumbens compared with unfertilized soils or soils subjected to acidity correction by liming but were not significantly different from soils treated with standard fertilizers. Therefore, fertilization with $3 \mathrm{Mg}$ $\mathrm{ha}^{-1}$ of turkey litter is recommended for improving degraded pastures.
\end{abstract}

Key words: Organic fertilization. Limestone Poultry litter. Brachiaria grass. Soil fertility.

\section{Resumo}

A correção da acidez e fertilidade do solo em área com pastagem em processo de recuperação exige maiores doses de corretivos/fertilizantes. Sendo assim, a utilização de produtos alternativos, de baixo custo, pode ser a alternativa em propriedades descapitalizadas. Diante disto, objetivou-se avaliar métodos de adubação e correção do solo na produtividade de Urochloa decumbens degradada e nos atributos

\footnotetext{
${ }^{1}$ Profs., Unidade Básica de Biociências, Centro Universitário de Mineiros, UNIFIMES, Mineiros, GO, Brasil. E-mail: andrisley@ fimes.edu.br; nice_engflorestal@hotmail.com; manolo@fimes.edu.br

2 Prof., Departamento de Engenharia Agrícola, Universidade Federal de Viçosa, UFV, Viçosa, MG, Brasil. E-mail: fernando. cunha@ufv.br

3 Prof., Universidade Federal de Mato Grosso do Sul, UFMS, Chapadão do Sul, MS, Brasil. E-mail: cassiano.roque@ufms.br

${ }^{4}$ Prof., Centro Universitário de Mineiros, Discente de Doutorado, Instituto Federal de Educação, Ciência e Tecnologia Goiano, IF Goiano, Campus Rio Verde, GO. Brasil. E-mail: diego@fimes.edu.br

* Author for correspondence
} 
químicos do solo. O experimento foi conduzido em Mineiros-GO entre outubro de 2011 e setembro de 2013 em Neossolo Quartzarênico órtico. Os tratamentos foram constituídos de aplicações de $2 \mathrm{Mg}$ ha ${ }^{-1}$ de calcário dolomítico, adubação convencional (45, 54 e $75 \mathrm{~kg} \mathrm{ha}^{-1}$ de N, P e K, respectivamente), $3 \mathrm{Mg} \mathrm{ha}^{-1}$ de cama de peru e a testemunha sem correção/fertilização. O delineamento experimental foi em blocos casualizados com quatro repetições. As parcelas experimentais foram constituídas de áreas úteis de 4,0 $\mathrm{m}^{2}$, com dimensões de 2,0 $\mathrm{m}$ de comprimento e largura. Foram avaliadas a produtividade de matéria seca de capim e os seguintes atributos químicos do solo: matéria orgânica, potencial hidrogeniônico ( $\mathrm{pH} \mathrm{em} \mathrm{CaCl}_{2}$ ), fósforo (Resina), potássio, cálcio, magnésio, capacidade de troca catiônica (CTC) e saturação por bases do solo. Os dados foram submetidos às análises de variância e a comparação de médias foram realizadas por meio do teste de Tukey a 0,05 de probabilidade. Verificouse que os manejos de adubação não afetaram o pH, potássio e CTC do solo. A adubação com cama de peru proporcionou maiores valores de matéria orgânica, fósforo, cálcio, magnésio e saturação por bases em relação aos solos que recebem ou não adubação convencional ou apenas calagem. A adubação com a cama de peru também proporcionou maior produtividade de massa seca da Urochloa decumbens em relação a solos não adubados ou que receberam apenas correção de acidez por calagem e não difere da adubação convencional. Recomenda-se a utilização da adubação com $3 \mathrm{Mg} \mathrm{ha}^{-1}$ de cama de peru para recuperação de pastagem degradada.

Palavras-chave: Adubação orgânica. Calcário. Cama aviária. Capim-braquiária. Fertilidade dos solos.

\section{Introduction}

In Brazil, $80 \%$ to $90 \%$ of pasture areas are composed of grasses of the genus Urochloa (SOUZA et al., 2016). These grasses are tolerant to the soil and climate conditions of the Cerrado. However, inadequate management and lack of corrective fertilization in soil establishment and maintenance to replenish nutrients in the soil contribute to the degradation of cultivated pastures (ALVES et al., 2014). The low supply of nitrogen and phosphorus together with the high saturation with aluminum are the primary limiting factors for the productivity of forages in soils of tropical regions (SOUZA et al., 2016), demonstrating the need of liming and nitrogen and phosphate fertilization in degraded areas.

Pasture degradation can be described as a dynamic process of degeneration or relative decrease in crop productivity. Pasture degradation causes significant economic losses and social damage in the affected region or property. Soil fertility management in degraded areas differs from that in areas cultivated recently or cultivated intensively for many years, being that the response to the use of fertilizers in degraded pastures increases during the recovery process (FOGEL et al., 2013), requiring high doses of correctives and fertilizers, as demonstrated by previous studies. Teixeira et al. (2015) cultivated vetiver grass in Haplic Cambisol and used doses of $2.67 \mathrm{Mg} \mathrm{ha}^{-1}$ of limestone and $257 \mathrm{mg} \mathrm{dm}^{-3}$ of phosphorus to recover a degraded area in Manaus, Amazonas. Santini et al. (2015) improved pastures of Urochloa decumbens in Ilha Solteira, São Paulo, and using dolomite limestone at a dose of $970 \mathrm{~kg}$ $\mathrm{ha}^{-1}$ (PRNT 90\%) to increase the base saturation $(\mathrm{V} \%)$ to $60 \%$. The nutrient sources used in the $\mathrm{N}$, $\mathrm{P}_{2} \mathrm{O}_{5}$, and $\mathrm{K}_{2} \mathrm{O}$ mixture were urea $(45 \% \mathrm{~N})$ at a dose of $50 \mathrm{~kg} \mathrm{ha}^{-1}$ of $\mathrm{N}$, single superphosphate $(18 \%$ $\mathrm{P}_{2} \mathrm{O}_{5}$ ) at a dose of $40 \mathrm{~kg} \mathrm{ha}^{-1}$ of $\mathrm{P}_{2} \mathrm{O}_{5}$, and potassium chloride $\left(60 \% \mathrm{~K}_{2} \mathrm{O}\right)$ at a dose of $30 \mathrm{~kg} \mathrm{ha}^{-1}$ of $\mathrm{K}_{2} \mathrm{O}$.

Silva et al. (2015) observed that the use of correctives, including limestone, could increase culture stability and maintain high dry matter (DM) yields in pastures. Most Brazilian Cerrado soils present poor chemical characteristics, including high acidity, high levels of exchangeable Al, and nutrient deficiency, particularly $\mathrm{Ca}, \mathrm{Mg}$, and P (ALVAREZ; RIBEIRO, 1999). These characteristics limit root growth and consequently decrease the capacity of absorption of water and nutrients. However, the literature disagrees on the best strategy to apply liming and reports that the choice of one or the other may lead to losses. 
One strategy is applying limestone on the surface of the soil without plowing. However, the low solubility of limestone may lead to low soil correction efficiency at greater depths, as is the case of Brachiaria grass, which grows in a soil layer of up to $65 \mathrm{~cm}$ (ALENCAR et al., 2009). Another strategy is incorporating limestone by plowing and harrowing. In this strategy, new application operations are necessary, thus increasing the cost of liming. In addition, plowing destroys soil aggregates, causing erosion and allowing the exposure of organic matter, leading to carbon losses (TIVET et al., 2013; AYE et al., 2016).

Therefore, new, efficient, and lost-cost strategies, including the use of litter, should be adopted to improve degraded pastures. In addition to liming, soil fertilization is necessary because the aerial part of improved pastures accumulates nutrients (SOUZA et al., 2016). Souza et al. (2016) reported that $60 \%$ of the farmers' production costs correspond to the use of fertilizers and correctives, reinforcing the need for more economical sources to improve degraded pastures. Fogel et al. (2013) observed that, among the existing litter material, poultry litter stands out primarily because it is cheap and easily accessible in Brazil. This material comes from poultry production plants, in which manure, feed remains, and feathers are accumulated during poultry growth and this material becomes rich in nutrients. Litter can be used as fertilizer and reduce the accumulation of residues in production facilities.

Other studies indicated that the use of litter in agriculture added chemical elements that could improve chemical, physical, and biological attributes of the soil (ARRUDA et al., 2014; SILVEIRA JÚNIOR et al., 2015; LIMA et al., 2016; OLIVEIRA et al., 2016). Arruda et al. (2014) evaluated the effect of poultry litter in substitution for chemical fertilizers on elephant grass pasture in Botucatu, São Paulo, and observed that regardless of the application form - single or split dose - the litter used as nitrogen fertilizer replaced urea in the cover fertilization of elephant grass.

Many studies indicate the advantages of using poultry litter for correcting soil acidity and fertility. However, few studies to date evaluated the effectiveness of turkey litter. Therefore, the objective of this study is to assess the effect of turkey litter compared with other methods of soil fertilization and correction on the productivity and soil chemical attributes of areas cultivated with Urochloa decumbens.

\section{Materials and Methods}

The experiment was conducted at Campus II of the Basic Biosciences Unit at the Experimental Farm Dr. Luiz Eduardo de Oliveira Sales at the University Center of Mineiros (Centro Universitário de Mineiros-UNIFIMES) located in Mineiros, Goiás, Brazil. The site has an altitude of $850 \mathrm{~m}$ and coordinates of $17^{\circ} 27^{\prime} 16.14^{\prime \prime} \mathrm{S}$ of latitude and $52^{\circ}$ $366^{\prime} 9.85^{\prime}$ 'W of longitude.

The study was conducted from October 2011 to September 2013. The evaluated area included degraded pastures of Urochloa decumbens Stapf. with an average annual stocking of $0.4 \mathrm{AU} \mathrm{ha}^{-1}$. The pasture was formed approximately 15 years prior and, since then, soil fertility was not managed until the beginning of the study.

The soil of the study area is classified as Orthic Quartzarenic Neosol (EMBRAPA, 2013), with medium texture and $15 \%$ of clay. Soil chemical attributes were determined in the Soil Laboratory of UNIFIMES in Mineiros, Goiás (Table 1). 
Table 1. Results of the chemical analysis of the $0-0.20 \mathrm{~m}$ soil layer of the experimental area. Mineiros, Goiás, UNIFIMES, 2011.

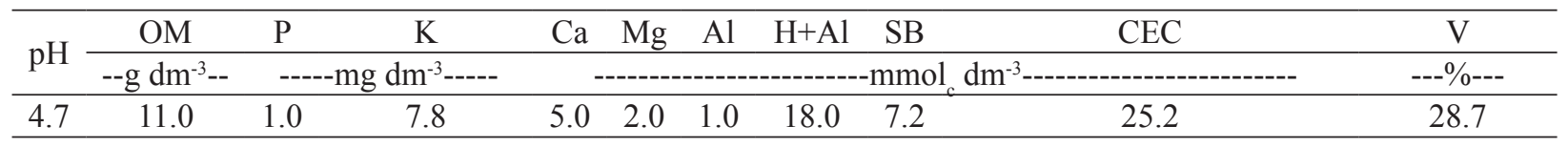

According to the classification of Köppen (1931), the climate of the region is Aw (tropical humid) with two well-defined seasons: a dry season in autumn and winter (from May and September) and a wet season with heavy rains in spring and summer.

During the experimental period, the data on the mean temperatures and rainfall were recorded daily at the Conventional Weather Station located on UNIFIMES campus (Figure 1). In the first year of the study (October 2011 to September 2012), total rainfall was $1,449 \mathrm{~mm}$ and average daily temperatures varied from $22.4{ }^{\circ} \mathrm{C}$ to $37.3^{\circ} \mathrm{C}$, with a mean of $29.2{ }^{\circ} \mathrm{C}$. In the second year (October 2012 to September 2013), total rainfall was $1,505 \mathrm{~mm}$ and average daily temperatures varied from $17.2^{\circ} \mathrm{C}$ to $37.7^{\circ} \mathrm{C}$, with a mean of $28.6{ }^{\circ} \mathrm{C}$.

Figure 1. Daily variations of air temperature $\left({ }^{\circ} \mathrm{C}\right)$ and rainfall (mm). Mineiros, Goiás, UNIFIMES, 2011-2013.

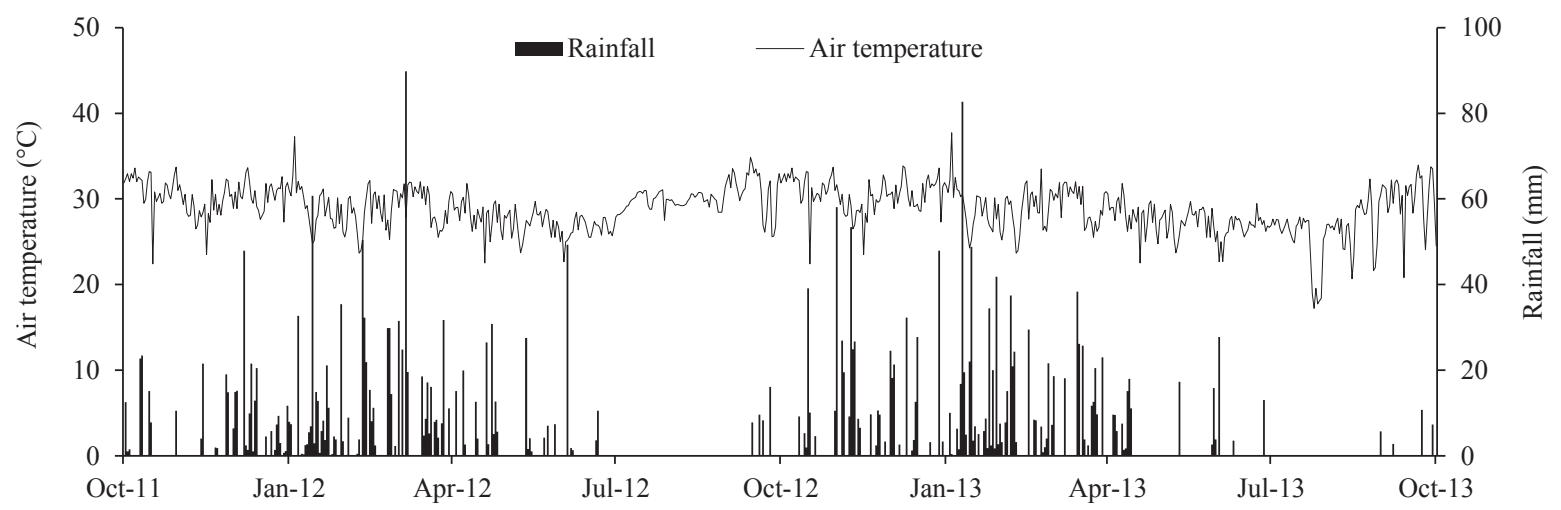

The experiment included four treatments, each with four replicates, in a completely randomized block design, with soil management. Soil management included methods for soil correction and fertilization of degraded pastures of Urochloa decumbens (Table 2). Soil fertilization occurred in October 2011 and October 2012. The experimental plots consisted of areas of $9 \mathrm{~m}^{2}(3.0 \times 3.0 \mathrm{~m})$. The border was $0.5 \mathrm{~m}$, resulting in a useful area of $4 \mathrm{~m}^{2}$.

Table 2. Soil management with soil correction and fertilization of degraded pastures of Urochloa decumbens. Mineiros, Goiás, UNIFIMES, 2011-2013.

\begin{tabular}{cccc}
\hline Treatments & Quantity & Unit & Nutrition score (\%) \\
\hline Control & & & 0 \\
Dolomite limestone & 2.000 & $\mathrm{~kg} \mathrm{ha}^{-1}$ & $\mathrm{Ca} 45 ; \mathrm{Mg}: 6 ;$ PRNT: 85 \\
NPK(20-0-20)+KCl+single superphosphate & $225+50+300$ & $\mathrm{~kg} \mathrm{ha}^{-1}$ & $\mathrm{~N}: 45 ; \mathrm{P}_{2} \mathrm{O}_{5}: 54 ; \mathrm{K}_{2} \mathrm{O}: 75$ \\
Turkey litter & 3.000 & $\mathrm{~kg} \mathrm{ha}^{-1}$ & $\mathrm{~N}: 85.2 ; \mathrm{P}_{2} \mathrm{O}_{5}: 106.5 ; \mathrm{K}_{2} \mathrm{O}: 74.5$ \\
\hline
\end{tabular}


The CFS (1995) provided guidelines on efficiency indices for the release of nutrients from the organic form to the mineral form. Fifty percent of nitrogen is released immediately after application and the rest is released gradually. Similarly, $50 \%$ of phosphorus is released immediately after application and the rest is released gradually, and potassium is released immediately. The chemical analysis of the original turkey litter used in the present study is shown in Table 3.

Table 3. Nutrient contents of turkey litter used in pasture fertilization. Mineiros, Goiás, UNIFIMES, 2011.

\begin{tabular}{ccccccc}
\hline $\mathrm{N}$ & $\mathrm{P}_{2} \mathrm{O}_{5}$ & $\mathrm{~K}_{2} \mathrm{O}$ & $\mathrm{Ca}$ & $\mathrm{Mg}$ & $\mathrm{S}$ & Moisture content \\
\hline & & & & & $\%$ & \\
\hline 4.0 & 5.0 & 3.5 & 3.2 & 0.46 & 0.2 & 29 \\
\hline
\end{tabular}

Source: Exata Laboratory, Jataí, Goiás, 2011.

The inputs were manually distributed on the day of the experiment. After applying the inputs, pasture mowing was initiated, always respecting the initial height of $0.30 \mathrm{~m}$ and final height of $0.15 \mathrm{~m}$ after grazing of forage grass.

The DM yield of forage grass was obtained manually in an area delimited by a metal quadrangular-shaped sampling unit with an edge of $1.0 \mathrm{~m}$ (useful area of $1.0 \mathrm{~m}^{2}$ ). The sampling unit was positioned at predetermined locations, and the collection of successive samples in the same areas was avoided. All the harvested green matter was packed in properly labeled plastic bags and their masses were measured immediately. Subsequently, subsamples were obtained, their masses were determined, and the samples were conditioned in properly labeled paper bags and dried in a greenhouse with forced air circulation at $65{ }^{\circ} \mathrm{C}$ for 72 hours. After drying, the masses of the subsamples were measured to determine the dry matter content and subsequently the DM yield of Urochloa decumbens in $\mathrm{Mg} \mathrm{ha}^{-1}$ year $^{-1}$.

After each cut, the remainder material in each experimental unit was cut with a brush cutter for homogenization. The cut material was scraped and removed from the experimental area to prevent its interference in later collections.

Soil data were collected after the last cut (October 2013) in the $0-0.20 \mathrm{~m}$ layer and six subsamples were collected to form a composite sample for each replicate. The soil samples were processed in the Laboratory of Soil Chemistry of UNIFIMES. The samples were air-dried and sieved in a $2.0 \mathrm{~mm}$-diameter sieve for separation of the coarser particles. The air-dried fine earth resulting from this procedure was stored for further analysis. The calculated parameters were organic matter, hydrogen potential (in $\mathrm{CaCl}_{2}$ ), phosphorus (resin), potassium, calcium, magnesium, cation exchange capacity, and soil base saturation according to EMBRAPA (2011).

Data were subjected to analysis of variance. The means were compared using Tukey's test at a level of significance of 0.05. Software $R$ version 3.3.2 ( $R$ DEVELOPMENT CORE TEAM, 2016) was used in all statistical analyses.

\section{Results and Discussion}

Regardless of the agricultural year, fertilization with turkey litter ( $\left.3 \mathrm{Mg} \mathrm{ha}^{-1}\right)$ or a standard fertilizer (NPK $+\mathrm{KCl}+$ single superphosphate) increased the DM yield of Urochloa decumbens compared with the other treatments (Table 4). Therefore, organic fertilizers may serve as agricultural inputs for recovering degraded pastures and pastures managed intensively for animal production. It is noteworthy that poultry litter can be applied superficially with no soil plowing, which minimizes erosion during 
pasture development (TIVET et al., 2013; AYE et al., 2016). In addition to pasture improvement, this strategy for disposal of residues (turkey litter) could reduce soil and water contamination in poultry production units.

It is of note that the DM yield of Urochloa decumbens was decreased from the first to the second agricultural year (Table 4). A possible justification is the distribution of rainfall because rainfall in the first year (115 events) was more distributed than in the second year (102 events) of cultivation (Figure 1). Another possibility is that the nutrient doses applied to the soil were not enough to guarantee a high DM yield in the second year. Fogel et al. (2013) corroborate this option, wherein the improvement of degraded pastures required high levels of nutrients to maintain the balance of the system. Similarly, Euclides et al. (2007) evaluated the deferment of grazing on Brachiaria pastures in the Cerrado region and observed a decrease in DM yield. These authors applied a dose of $200 \mathrm{~kg}$ $\mathrm{ha}^{-1}$ of the NPK 0-20-20 formula and, at the time of grazing deferment, $110 \mathrm{~kg} \mathrm{ha}^{-1}$ of urea were applied annually as coverage. The authors observed that the maximum DM yield of $4.6 \mathrm{mg} \mathrm{ha}^{-1}$ year ${ }^{1}$ was reduced to $3.7 \mathrm{mg} \mathrm{ha}^{-1}$ year ${ }^{-1}$ in the second agricultural year.

Table 4. Mean values of dry matter yield in the first agricultural year (MS1) and second agricultural year (MS2), organic matter $(\mathrm{OM})$, hydrogen potential $(\mathrm{pH})$, phosphorus $(\mathrm{P})$, potassium $(\mathrm{K})$, calcium $(\mathrm{Ca})$, magnesium $(\mathrm{Mg})$, cation exchange capacity (CEC), and base saturation (V) in the $0-20 \mathrm{~cm}$ soil layer using different techniques for managing acidity and fertility. Mineiros, Goiás, UNIFIMES, 2011-2013.

\begin{tabular}{|c|c|c|c|c|c|}
\hline Treatments & $\begin{array}{c}\text { MS1 } \\
\left(\mathrm{Mg} \mathrm{ha}^{-1} \text { year }^{-1}\right)\end{array}$ & $\begin{array}{c}\text { MS2 } \\
\left(\mathrm{Mg} \mathrm{ha}^{-1} \text { year }^{-1}\right)\end{array}$ & $\begin{array}{c}\mathrm{OM} \\
\left(\mathrm{g} \mathrm{dm}^{-3}\right)\end{array}$ & $\mathrm{pH}$ & $\begin{array}{c}\mathrm{P} \\
\left(\mathrm{mg} \mathrm{dm}^{-3}\right) \\
\end{array}$ \\
\hline $3 \mathrm{Mg} \mathrm{ha}^{-1}$ turkey litter & $12.0 \mathrm{a}$ & $7.0 \mathrm{a}$ & $24.5 \mathrm{a}$ & $5.2 \mathrm{a}$ & $6.5 \mathrm{a}$ \\
\hline $\mathrm{NPK}+\mathrm{KCl}+\mathrm{SS}$ & $11.5 \mathrm{a}$ & $6.7 \mathrm{a}$ & $24.3 \mathrm{ab}$ & $5.1 \mathrm{a}$ & $2.5 \mathrm{~b}$ \\
\hline $2 \mathrm{Mg} \mathrm{ha}^{-1}$ limestone & $4.5 \mathrm{~b}$ & $3.6 \mathrm{~b}$ & $21.8 \mathrm{~b}$ & $5.4 \mathrm{a}$ & $1.3 \mathrm{~b}$ \\
\hline Control & $4.9 \mathrm{~b}$ & $3.3 \mathrm{~b}$ & $21.8 \mathrm{~b}$ & $5.2 \mathrm{a}$ & $1.5 \mathrm{~b}$ \\
\hline CV $(\%)$ & 15.82 & 13.05 & 5.02 & 5.02 & 59.03 \\
\hline Treatments & $\begin{array}{c}\mathrm{K} \\
\left(\mathrm{mg} \mathrm{dm}^{-3}\right)\end{array}$ & $\begin{array}{c}\mathrm{Ca} \\
\left(\mathrm{mmol}_{\mathrm{c}} \mathrm{dm}^{-3}\right)\end{array}$ & $\begin{array}{c}\mathrm{Mg} \\
\left(\mathrm{mmol}_{\mathrm{c}} \mathrm{dm}^{-3}\right)\end{array}$ & $\begin{array}{c}\mathrm{CEC} \\
\left(\mathrm{mmol}_{\mathrm{c}} \mathrm{dm}^{-3}\right)\end{array}$ & $\begin{array}{c}\mathrm{V} \\
(\%)\end{array}$ \\
\hline $3 \mathrm{Mg} \mathrm{ha}^{-1}$ turkey litter & $30.7 \mathrm{a}$ & $16.0 \mathrm{a}$ & $7.8 \mathrm{a}$ & $40.8 \mathrm{a}$ & $41.5 \mathrm{a}$ \\
\hline $\mathrm{NPK}+\mathrm{KCl}+\mathrm{SS}$ & $29.1 \mathrm{a}$ & $9.5 \mathrm{~b}$ & $4.5 \mathrm{~b}$ & $41.5 \mathrm{a}$ & $33.3 \mathrm{~b}$ \\
\hline $2 \mathrm{Mg} \mathrm{ha}^{-1}$ limestone & $23.3 \mathrm{a}$ & $14.5 \mathrm{ab}$ & $7.5 \mathrm{ab}$ & $35.1 \mathrm{a}$ & $40.8 \mathrm{a}$ \\
\hline Control & $19.4 \mathrm{a}$ & $11.0 \mathrm{ab}$ & $5.0 \mathrm{ab}$ & $33.3 \mathrm{a}$ & $35.1 \mathrm{ab}$ \\
\hline $\mathrm{CV}(\%)$ & 27.67 & 22.25 & 25.80 & 11.86 & 13.64 \\
\hline
\end{tabular}

The means followed by the same letter in each column are not significantly different using Tukey's test $(p<0.05)$.

At the end of the study period, the soil fertilized with turkey litter was not significantly different from the soil treated with a standard fertilizer (NPK $+\mathrm{KCl}+$ single superphosphate) and the organic matter content was higher than that of the control soil and the soil fertilized with limestone (Table 4). Treatment with turkey litter caused a 123\% increase in soil organic matter compared with baseline values (Table 1). These results evidence the potential of turkey litter in the recovery of degraded pastures.
Silva et al. (2012) applied 2.4 Mg ha-1 year-1 of turkey litter in improving pastures of Urochloa decumbens in Uberlândia, Minas Gerais, and found that $88 \%$ of the organic matter was present in the $0-20 \mathrm{~cm}$ soil layer.

Fertilization management of Urochloa decumbens did not affect soil $\mathrm{pH}$ (Table 4). These results corroborate with those of Silva et al. (2012), who applied fertilizers (organic, mineral, and 
organo-mineral) in degraded pastures of Urochloa decumbens in Uberlândia, Minas Gerais, and did not observe differences in soil $\mathrm{pH}$ in the 8-month study period. Our results indicated that the $\mathrm{pH}$ increased by $15 \%$ compared with baseline values (Table 1 ). This increase is due to the use of the soil by pasture. The electrons accumulated during respiration are discharged into reducing compounds, which react with the $\mathrm{H}^{+}$of the environment, decreasing $\mathrm{pH}$ concentration (LIMA et al., 2012).

Fertilization with turkey litter increased soil phosphorus content compared with the other treatments (Table 4). Phosphorus content was increased by $550 \%$ compared with baseline values (Table 1) possibly because turkey litter presented high levels of this nutrient (Table 3). These results are relevant because the fixation of phosphorus tends to be high in this type of soil, which limits the increase in the levels of this element.

The different fertilization treatments did not affect the potassium content of the soil after 2 years of application (Table 4). The low increase in potassium levels may be due to the use of low doses of chemical and organic fertilizers. Another critical factor is the possible leaching of this nutrient because of the high amount of sand in these soils, favoring the transport of this element. The high rate of leaching is because potassium presents a single positive charge $\left(\mathrm{K}^{+}\right)$and is poorly adsorbed by soil colloids (ERNANI et al., 2007). Therefore, potassium leaching is higher in soils with good drainage and lower CEC values (RAIJ, 2011). Duarte et al. (2013) found that potassium from $\mathrm{KCl}$ moved vertically, reaching all soil levels of the lysimeter, indicating higher percolation of this element in the soil column, which was expected because potassium is soluble in water. Silva et al. (2012) applied different fertilizers (organic, mineral, and organo-mineral) to degraded areas containing Urochloa decumbens in Uberlândia, Minas Gerais, and did not find differences in the potassium content of the soil in the 8-month study period. Similarly, Pinto et al. (2012) found no significant differences in potassium levels in the $10-20 \mathrm{~cm}$ soil layer using turkey litter to improve degraded pastures of Urochloa decumbens in Portelândia, Goiás, corroborating the results of the present study.

A similar result was obtained for calcium and magnesium. At the end of the study period, the levels of calcium and magnesium in soil treated with turkey littler were not significantly different from those in the control soil and soil treated by liming but were higher than those in soil treated with a standard fertilizer (Table 4). This result was expected because turkey littler has these two elements in contrast to standard fertilizers. The calcium and magnesium levels in soils fertilized with turkey litter were increased by $220 \%$ and $290 \%$, respectively, compared with baseline values (Table 1). Silveira Júnior et al. (2015) evaluated Urochloa brizantha cv. Piatã in Araguaína, Tocantins, and applied a chemical fertilizer and different levels of poultry litter and observed an increase in the levels of calcium and magnesium in the soil in all treatments.

The different treatments used for fertilizing pastures of Urochloa decumbens did not affect soil CEC (Table 4). The CEC did not change significantly probably because potassium did not respond to the different fertilization conditions. It should be noted that, in the present study, potassium was the predominant element in the composition of the CEC. It is possible that CEC was increased by $50 \%$ compared with baseline values because of the reasons described previously (Table 1). Silveira Júnior et al. (2015) used a chemical fertilizer and different levels of poultry litter and observed a $96 \%$ increase in soil CEC compared with baseline values.

The V values in the plots treated with turkey litter and liming did not differ from the control and were higher than the plots treated with a standard fertilizer (Table 4). This result indicates an increase in the exchangeable bases with turkey litter as fertilizer. This effect is beneficial in pasture soils because the grass type used in this study requires approximately 
$35 \%$ base saturation, which is achieved by successive application of turkey litter. Pinto et al. (2012) evaluated the recovery of degraded areas containing Urochloa decumbens in Portelândia, Goiás, and observed that baseline saturation values in a control soil and soil fertilized with turkey litter were $29.8 \%$ and $44.0 \%$ (0-5 cm layer), $22.3 \%$ and $34.9 \%$ (5-10 cm layer), and $20.2 \%$ and $30.8 \%$ (10$20 \mathrm{~m}$ layer), respectively.

A result that should also be emphasized in the present study was that the control soil presented better chemical attributes at the end of the study period. This result indicates that proper pasture management (animal inflow and outflow) improves soil chemical attributes and dry matter yield, corroborating the results of Alves et al. (2014) and Souza et al. (2016). The evaluated pasture was cultivated for 15 years using the extensive system, characterized by constant cuts by grazing at wrong intervals. Since the beginning of the study, the pasture height was taken into consideration for the execution of the cuts, and $15 \%$ of the remaining green leaves were left on the pasture after mowing (AROEIRA et al., 1999). The root system may develop further in these conditions, allowing the use of deep soil and promoting nutrient cycling.

\section{Conclusions}

Fertilization with $3 \mathrm{Mg} \mathrm{ha}^{-1}$ of turkey litter provides higher dry matter yield of Urochloa decumbens compared with unfertilized soils and soils fertilized with liming but does not differ from standard fertilization with $\mathrm{NPK}+\mathrm{KCl}+$ single superphosphate.

Fertilization with $3 \mathrm{Mg} \mathrm{ha}^{-1}$ of turkey litter is recommended for increasing organic matter yield, base saturation, phosphorus, calcium, and magnesium.

The treatments used for correcting soil acidity and fertility do not affect soil $\mathrm{pH}$, potassium levels, and CEC.

\section{References}

ALENCAR, C. A. B.; CUNHA, F. F.; MARTINS, C. E.; CÓSER, A. C.; ROCHA, W. S. D.; ARAÚJO, R. A. S. Irrigação de pastagem: atualidade e recomendações para uso e manejo. Revista Brasileira de Zootecnia, Viçosa, MG, v. 38, p. 98-108, 2009. Número Especial.

ALVAREZ, V. H.; RIBEIRO, A. C. Calagem. In: RIBEIRO, A. C.; GUIMARÃES, P. T. G.; ALVAREZ, V. H. (Ed.). Recomendações para o uso de corretivos e fertilizantes em Minas Gerais. Viçosa, MG: Editora UFV, 1999. p. 43-60.

ALVES, F. G. S.; FELIX, B. A.; PEIXOTO, M. S. M.; SANTOS, P. M.; COSTA, R. B.; SALES, R. O. Considerações sobre manejo de pastagens na região semiárida do Brasil: Uma revisão. Revista Brasileira de Higiene e Sanidade Animal, Fortaleza, v. 8, n. 4, p. 259283, 2014.

AROEIRA, L. J. M.; LOPES, F. C. F.; DERESZ, F.; VERNEQUE, R. S.; DAYRELL, M. S.; MATOS, L. L.; MALDONADO VASQUEZ, H.; VITTORI, A. Pasture availability and dry matter intake of lactating crossbred cows grazing elephant grass (Pennisetum purpureum, Schum.). Animal Feed Science and Technology, Amsterdam, v. 78, n. 3, p. 313-324, 1999.

ARRUDA, G. M. M. F.; FACTORI, M. A.; COSTA, C.; MEIRELlES, P. R. L.; SILVA, M. B.; LIMA, V. L. F.; HADLICH, J. C.; SILVA, M. P. Produtividade e composição proteica do capim-elefante recebendo adubação orgânica e mineral. Revista Acadêmica de Ciências Agrárias e Ambientais, Curitiba, v. 12, n. 1, p. 61-69, 2014.

AYE, N. S.; SALE, P. W.; TANG, C. The impact of long-term liming on soil organic carbon and aggregate stability in low-input acid soils. Biology and Fertility of Soils, New York, v. 52, n. 3, p. 697-709, 2016.

COMISSÃO DE FERTILIDADE DO SOLO - CFS-RS/ SC (Passo Fundo, RS). Recomendações de adubação e calagem para os Estados do Rio Grande do Sul e Santa Catarina. 3. ed. Passo Fundo: Sociedade Brasileira de Ciência do Solo/Embrapa, 1995. 224 p.

DUARTE, I. N.; PEREIRA, H. S.; KORNDÖRFER, G. H. Lixiviação de potássio proveniente do termopotássio. Pesquisa Agropecuária Tropical, Goiânia, v. 43, n. 2, p. 195-200, 2013.

EMPRESA BRASILEIRA DE PESQUISA AGROPECUÁRIA - EMBRAPA. Manual de métodos de análise de solo. 2. ed. Rio de Janeiro: Embrapa Solos, 2011. $230 \mathrm{p}$. 
Sistema brasileiro de classificação de solos. 3 . ed. Rio de Janeiro: Embrapa Solos, 2013. 353 p.

ERNANI, P. R.; BAYER, C.; ALMEIDA, J. D.; CASSOL, P. C. Mobilidade vertical de cátions influenciada pelo método de aplicação de cloreto de potássio em solos com carga variável. Revista Brasileira de Ciência do Solo, Viçosa, MG, v. 31, n. 2, p. 393-402, 2007.

EUCLIDES, V. P. B.; FLORES, R.; MEDEIROS, R. N.; OLIVEIRA, M. P. Diferimento de pastos de braquiária cultivares Basilisk e Marandu, na região do Cerrado. Pesquisa Agropecuária Brasileira, Brasília, v. 42, n. 2, p. 273-280, 2007.

FOGEL, G. F.; MARTINKOSKI, L.; MOKOCHINSKI, F. M.; GUILHERMETTI, P. G. C.; MOREIRA, V. S. Efeitos da adubação com dejetos suínos, cama de aves e fosfato natural na recuperação de pastagens degradadas. Revista Verde de Agroecologia e Desenvolvimento Sustentável, Mossoró, v. 8, n. 5, p. 66-71, 2013.

KÖPPEN, W. Grundriss der klimakunde: outline of climate science. Berlin: Walter de Gruyter, 1931. 388 p.

LIMA, E. S. A.; AMARAL SOBRINHO, N. M. B.; MAGALHÃES, M. O. L.; GUEDES, J. N.; ZONTA, E. Absorção de bário por plantas de arroz (Oryza sativa L.) e mobilidade em solo tratado com baritina sob diferentes condições de potencial redox. Química Nova, São Paulo, v. 35, n. 9, p. 1746-1751, 2012.

LIMA, V. L. F.; DUCATTI, C.; MEIRELLES, P. R.; SERAPHIM, L. C.; FACTORI, M. A.; JORGE, A. M.; VILLAS BÔAS, R. L.; SILVA, M. G. B. Isotopic of nitrogen and chemical analysis of deferred grazing marandu palisadegrass fertilized with urea and poultry litter. Semina: Ciências Agrárias, Londrina, v. 37, n. 4, p. 2609-2622, 2016.

OLIVEIRA, J. G. R.; TAVARES FILHO, J.; BARBOSA, G. M. C. Alterações na física do solo com a aplicação de dejetos animais. Geographia Opportuno Tempore, Londrina, v. 2, n. 2, p. 66-80, 2016.

PINTO, F. A.; SANTOS, F. L.; TERRA, F. D.; RIBEIRO, D. O.; RODRIGUES, R.; SOUSA, J.; SOUSA, E. D.; CARNEIRO, M. A. C.; PAULINOS, H. B.; Atributos de solo sob pastejo rotacionado em função da aplicação de cama de peru. Pesquisa Agropecuária Tropical, Goiânia, v. 42, n. 3, p. 254-262, 2012.

R DEVELOPMENT CORE TEAM - R: A language and environment for statistical computing. Vienna: Foundation for Statistical Computing. Vienna: R Foundation, 2016. Available at: $<$ http://www.R-project. org/>. Accessed at: 21 sept. 2016.
RAIJ, B. V. Fertilidade do solo e manejo dos nutrientes. Piracicaba: International Plant Nutrition Institute, 2011. $420 \mathrm{p}$.

SANTINI, J. M. K.; BUZETTI, S.; GALINDO, F. S.; DUPAS, E.; COAGUILA, D. N. Técnicas de manejo para recuperação de pastagens degradadas de capimbraquiária (Brachiaria decumbens stapf cv. Basilisk). Boletim de Indústria Animal, Nova Odessa, v. 72, n. 4, p. 331-340, 2015.

SILVA, A. A.; COSTA, A. M.; LANA, R. M. Q.; LANA, A. M. Q. Recycling of nutrients with application of organic waste in degraded pasture. Engenharia Agrícola, Jaboticabal, v. 32, n. 2, p. 405-414, 2012.

SILVA, M. R.; PELISSARI, A.; MORAES, A.; SANDINI, I. E.; CASSOL, L. C.; ASSMANN, T. S.; OLIVEIRA, E. B. Acumulação de nutrientes e produção forrageira de aveia e azevém em função da aplicação de calcário e gesso em superfície. Revista de Ciências Agrárias, Lisboa, v. 38, n. 3, p. 346-356, 2015.

SILVEIRA JÚNIOR, O.; SANTOS, A. C.; ROCHA, J. M. L.; FERREIRA, C. L. S.; OLIVEIRA, L. B. T.; RODRIGUES, M. O. D.; RODRIGUES, M. O. D. Implantação de pastagens sob sistema monocultivo e integrado com lavoura utilizando biofertilizante de cama de aviário como adubação de cobertura. Revista Brasileira de Saúde e Produção Animal, Salvador, v. 16, n. 3, p. 499-512, 2015.

SOUZA, F. M.; LEMOS, B. J. M.; OLIVEIRA JUNIOR, R. C.; MAGNABOSCO, C. U.; CASTRO, L. M.; LOPES, F. B.; BRUNES, L. C. Introdução de leguminosas forrageiras, calagem e fosfatagem em pastagem degradada de Brachiaria brizantha. Revista Brasileira de Saúde e Produção Animal, Salvador, v. 17, n. 3, p. 355-364, 2016.

TEIXEIRA, P. C.; MESQUITA, I. L.; MACEDO, S. T.; TEIXEIRA, W. G.; LIMA, W. A. A. Resposta de vetiver à aplicação de calcário e fósforo em três classes de solo. Revista Brasileira de Engenharia Agrícola e Ambiental, Campina Grande, v. 19, n. 2, p. 99-105, 2015.

TIVET, F.; SÁ, J. C. M.; LAL, R.; BRIEDIS, C.; BORSZOWSKEI, P. R.; SANTOS, J. B.; FARIAS, A.; EURICH, G.; HARTMAN, D. C.; NADOLNY JUNIOR, M.; BOUZINAC, S.; SÉGUY, L. Aggregate C depletion by plowing and its restoration by diverse biomass-C inputs under no-till in sub-tropical and tropical regions of Brazil. Soil and Tillage Research, New York, v. 126, n. 1, p. 203-218, 2013. 
